Books In / As / Through Books

Dr. Frank Serafini

Associate Professor - Literacy Education Mary Lou Fulton Teachers College

Arizona State University serafini@asu.edu (702) 493-7073

Felicia Tompkins Graduate Student Arizona State University 
Calls for young readers to engage with more complex texts have emerged in response to curriculum mandates outlined in the Common Core State Standards (Pearson \& Hiebert, 2013). Complexity is not a matter of simply increasing the length of the books we ask students to read; it is about engaging students in deeper conversations, reading more complex narratives, and considering both the textual and visual aspects of contemporary picturebooks. Providing picturebooks with diverse narrative structures, complex design features, and sophisticated visual images can increase the level of complexity in the books being read and benefit the reading experiences of elementary age readers (Pantaleo \& Sipe, 2012).

In recent years, literacy educators have investigated how young readers respond to various metafictive or radical change elements in contemporary, postmodern picturebooks (Dresang, 1999; Sipe \& Pantaleo, 2008). One element associated with contemporary and postmodern picturebooks we have found interesting is the use of books as visual and narrative objects displayed inside picturebooks. For example, in various contemporary picturebooks, the covers of the books themselves have been displayed in miniature form as a visual object or mise en abyme in the illustrations. Books have also been personified, coming to life and serving as characters in the story. In addition, books have served as portals or entrances to alternate storyworlds. In this column, we will explore a variety of contemporary picturebooks that exhibit these characteristics and offer some ways these picturebooks may be integrated into the elementary reading curriculum.

\section{Books as Objects}

Books have been featured as objects of contemplation in the verbal and visual narratives in picturebooks focusing on the act of reading and the challenges of becoming 
a reader (Serafini, 2004). For example, in Wolf(Bloom, 1999), The Wednesday Surprise (Bunting, 1989), and Thank You, Mr. Falker (Polacco, 1998) the focus of the story has been the process of becoming a reader. Books have also been part of the storyline in various historical fiction picturebooks that focus on the power of being literate, for example More Than Anything Else (Bradby, 1995) and Richard Wright and the Library Card (Miller, 1997). In addition, there are times when books have even been featured as an object of consumption, as in the humorous picturebook The Incredible Book Eating Boy (Jeffers, 2006).

In several picturebooks reviewed for this column, the book is presented as an object under construction, where the book itself is portrayed as being constructed as it is being read. In An Undone Fairy Tale (Lendler, 2005), No Bears (McKinley, 2011), Do Not Open This Book! (Muntean, 2006), Don't Read This Book! (Lewis, 2009), and A Story with Pictures (Kanninen, 2007) the picturebook narrative and illustrations are incomplete and the reader needs to be warned about the impending challenges of reading these books. A narrator, in each of these cases posing as the author or illustrator of the original story, disrupts the initial narrative to warn the reader that the story is not complete and still under construction.

In other picturebooks, the original story has been significantly changed by a disruptive narrator, actually a character in the book, as in Chester's Masterpiece (Watt, 2010), or the reader is warned not to proceed because they will encounter dangerous elements in the story, for example monkeys in Warning: Do Not Open this Book! (Lehrhaupt, 2013), crocodiles in Open Vary Carefully: A Book with Bite (O'Byrne, 2013), 
a monster in The Monster at the End of This Book (Stone, 1971), and an annoying salesperson in Have I Got a Book for You! (Watt, 2009).

These picturebooks offer a second level of narrative which disrupts the original narrative or diegesis, a term used to describe the initial storyworld, the world created by the author-illustrator into which the story events take place (Abbott, 2008). This disruption or metalepsis (Genette, 1999) calls readers' attention to the boundaries among the real world readers inhabit, the storyworld of the original narrative, and the storyworld the fictional narrator inhabits. This breaking of narrative boundaries requires readers to navigate between the various levels of these complex texts to enjoy the humor in these stories and understand what is happening (Pantaleo, 2010). What appears to be simple picturebooks are actually complex, diverse narratives that will challenge and entertain young readers.

\section{Books as Characters}

In some picturebooks, books come to life and become characters in the story. In The Fantastic Flying Books of Mr. Morris Lessmore (Joyce, 2012) books take on human characteristics as they guide the main character to a new place to live, urge him to read the stories inside themselves, and eventually care for Morris as he grows older. Taking personification a step further, The Book That Eats People (Perry, 2009) warns the reader it is not a book, not a story or a poem, but a dangerous, human-eating book. The bright red cover displays sinister eyes that stare out at the reader and cautions the reader to beware when entering the story.

\section{Books as Portals to Alternate Storyworlds}


Books also serve as portals to other storyworlds, in much the same manner as a wardrobe or train station platform served as entrances to other worlds in the Chronicles of Narnia and the Harry Potter books. In these books, the characters leaves the original storyworld behind by stepping into an alternate storyworld created within the book.

In A Book (Gerstein, 2009), We Are in a Book! (Willems, 2010), Who's Afraid of the Big Bad Book? (Child, 2002), and A Bad Day at Riverbend (Van Allsburg, 1995) the characters and reader are transported to another world or second level narrative that exists within the covers of the book they are reading. The metafictive device of calling attention to the narrative reality of the book itself forces the reader into a more active stance, requiring them to work back and forth across narrative storyworlds to understand what is happening.

This narrative technique can also transform informational texts into an exploration of unfamiliar territory. In Coral Reefs (Chin, 2011), the main character chooses a book from the library, begins reading about coral reefs, and before she knows it the library transforms into an under water world.

Utilizing the picturebook as an object of construction, as a character, and as portals to other narrative levels breaks the traditional boundaries between fictional and real worlds by involving the reader in the narrative, talking to them directly, and requiring them to actively participate in the construction of the narrative (Sipe, 1998). Picturebooks requiring this more active level of participation is reminiscent of Barthes (1977) distinction between readerly and writerly texts, where writerly texts, like the complex picturebooks described here, engage the reader as co-author and active participant in the reading process. As teachers work to increase the complexity of the 
texts they ask students to engage with, considering the types of diverse narratives described in this column will serve them better than simply requiring students to read longer books.

\section{References}

Abbott, H. P. (2008). The Cambridge introduction to narrative (2nd ed.). Cambridge: Cambrideg University Press.

Barthes, R. (1977). The rhetoric of the image. In R. Barthes (Ed.), Image, Music, Text (pp. 32-51). New York: Hill and Wang.

Bloom, B. (1999). Wolf! New York: Orchard Books.

Bradby, M. (1995). More Than Anything Else. New York: Orchard.

Bunting, E. (1989). The Wednesday Surprise. New York: Clarion Books.

Child, L. (2002). Who's Afraid of the Bid Bad Book? New York: Hyperion.

Chin, J. (2011). Coral Reefs. New York: Roaring Book Press.

Dresang, E. T. (1999). Radical change: Books for youth in a digital age. New York: H. W. Wilson.

Genette, G. (1999). Palimpsets (C. Newman \& C. Doubinsky, Trans.). Lincoln, NE: University of Nebraska Press.

Gerstein, M. (2009). A Book. New York: Roaring Book Press.

Jeffers, O. (2006). The Incredible Book Eating Boy. New York: Philomel Books.

Joyce, W. (2012). The Fantastic Flying Books of Mr. Morris Lessmore. New York: Atheneum Books.

Kanninen, B. (2007). A Story with Pictures. New York: Holiday House.

Lehrhaupt, A. (2013). Warning: Do Not Open this Book! New York: Simon \& Schuster. 
Lendler, I. (2005). An Undone Fairy Tale. New York: Simon \& Schuster.

Lewis, J. (2009). Don't Read This Book! London: Egmont UK Limited.

McKinley, M. (2011). No Bears. Somerville, MA: Candlewick Press.

Miller, W. (1997). Richard Wright and the Library Card. New York: Lee \& Low.

Muntean, M. (2006). Do Not Open This Book! New York: Scholastic.

O'Byrne, N. (2013). Open Very Carefully: A Book with Bite. Somerville, MA: Candlewick Press.

Pantaleo, S. (2010). Mutinous fiction: Narrative and illustrative metalepsis in three postmodern picturebooks. Children's Literature in Education, 41, 12-27.

Pantaleo, S., \& Sipe, L. R. (2012). Diverse narrative structures in contemporary picturebooks: Opportunities for children's meaning-making. Journal of Children's Literature, 38(1), 6-15.

Pearson, P. D., \& Hiebert, E. H. (2013). Understanding the common core standards. In L. M. Morrow, K. K. Wixson \& T. Shanahan (Eds.), Teaching with the common core standards for English language arts: Grades 3-5. (pp. 1-21). New York: Guilford.

Perry, J. (2009). The Book That Eats People. Berkeley: Tricycle Press.

Polacco, P. (1998). Thank You, Mr. Falker. New York: Philomel.

Serafini, F. (2004). Images of reading and the reader. The Reading Teacher, 57(5), 22-33.

Sipe, L. R. (1998). How picture books work: A semiotically framed theory of text-picture relationships. Children's Literature in Education, 29(2), 97-108.

Sipe, L. R., \& Pantaleo, S. (Eds.). (2008). Postmodern picturebooks: Play, parody, and self-referentiality. New York: Routledge.

Stone, J. (1971). The Monster at the End of This Book. New York: Sesame Workshop. 
Van Allsburg, C. (1995). Bad Day at Riverbend. New York: Houghton Mifflin.

Watt, M. (2009). Have I Got a Book for You! Toronto: KIds Can Press.

Watt, M. (2010). Chester's Masterpiece. Toronto: Kids Can Press.

Willems, M. (2010). We Are in a Book! New York: Hyperion. 